Beata Karpeta-Peć

Uniwersytet Warszawski

beata.pec@uw.edu.pl

\title{
INNOWACYJNE ROZWIAZZANIA GLOTTODYDAKTYCZNE W KSZTAŁCENIU KOMPETENCJI MIĘDZYKULTUROWEJ
}

\author{
Innovative glottodidactic (learning/teaching) solutions in teaching \\ cross-cultural competence
}

The aim of this article is to present various innovative solutions, which can be used in foreign language teaching and learning. The essence of the discussion is the attempt to systematise the suggestions in the field of glottodidactics, which enable to fulfil the paramount aim of foreign language learning and teaching, that is the development of the cross-cultural competence.

Keywords: innovation, cross-cultural competence, cross-cultural work forms typology, open forms, glottodidactic solutions

Słowa kluczowe: innowacyjność, kompetencja międzykulturowa, typologia międzykulturowych form pracy, otwarte formy pracy

\section{Wprowadzenie}

Niniejszy artykuł ma być zachętą do nauczania języków obcych zorientowanego w ten sposób, aby stało się miejscem poznania człowieka jako osoby wzrastającej w określonej kulturze. Poszukiwania nie będą globalnym spojrzeniem na problematykę międzykulturowości, nie będą też dotyczyć akwizycji języka w aspekcie międzykulturowym, lecz skoncentrują się wokół uczenia się i nauczania języka obcego. Zamysłem autorki niniejszego artykułu jest usystematyzowanie istniejących rozwiązań glottodydaktycznych, sprzyjających innowacyjności, w zakresie kształcenia kompetencji międzykulturowej. Jego sedno stanowi zestawienie propozycji takich rozwiązań oraz usystematyzowanie ich we własnej 
typologii form pracy międzykulturowego uczenia się i nauczania języków obcych (przy czym procesy uczenia się wyeksponowane zostają wobec procesów nauczania - zgodnie z aktualnie obowiązującymi zasadami w glottodydaktyce).

\section{Kompetencja międzykulturowa oraz innowacyjność w glottodydaktyce}

Na wstępie należy zauważyć, że „podstawą językowej polityki europejskiej jest poszanowanie różnorodności dziedzictwa kulturowego, językowego i edukacyjnego wszystkich Europejczyków" (Gajek, 2004: 9). Takie pojęcia jak uczenie się międzykulturowe, komunikacja międzykulturowa, wychowanie międzykulturowe, pedagogika międzykulturowa funkcjonują w literaturze przedmiotu od lat 80-tych XX w. (por. Torenc, 2007: 58). W dziedzinie pedagogiki międzykulturowe uczenie się postrzegane jest jako cel uczenia się oraz zasada nauczania i rozumiane jako „zdolność uczenia się i życia w społeczeństwie wielokulturowym" (Krumm, 1995: 156). W glottodydaktyce kompetencja międzykulturowa rozumiana jest jako „umiejętność wielo-perspektywicznego postrzegania sytuacji związanych z obcą kulturą, empatii i krytycznej tolerancji wobec niej oraz jej członków" (Heyd, 1997). Obejmuje ona:

- umiejętność rozumienia i interpretowania z własnego punktu widzenia obcej kultury, oczekiwań wobec ról społecznych pełnionych przez jej członków oraz ich zachowań;

- rozumienie procesów zachodzących podczas interakcji osób pochodzących z różnych kultur w tzw. sytuacjach międzykulturowych;

- dysponowanie strategiami radzenia sobie z sytuacjami międzykulturowymi oraz rozumienia obcego świata na tle własnego (por. tamże). Lekcje języków obcych są zatem miejscem systematycznych spotkań uczących się z obcą kulturą, (re)prezentowaną przez osoby, z którymi bezpośrednio lub pośrednio odbywa się komunikacja. Każda taka lekcja jest na wskroś międzykulturowa i oznacza poznawanie kultury kraju docelowego i jego języka na bazie własnych doświadczeń, aczkolwiek z perspektywy własnej kultury. Rozwijanie kompetencji międzykulturowej jest celem doprecyzowanym w ramach kształcenia kompetencji komunikacyjnej i tak jest rozumiane w niniejszym artykule.

Innowacyjność natomiast w tym kontekście postrzegana jest jako proces, w odróżnieniu od spontanicznych jednorazowych działań, mających na celu wypróbowanie dobrych pomysłów i tzw. dobrych praktyk (por. de Cillia i in., 2005: 68). Proces innowacyjności obejmuje takie etapy, jak: badanie sytuacji wyjściowej, pozwolenie na wprowadzenie innowacji (np. ze strony dyrekcji szkoły), diagnozę (czyli zdefiniowanie problemu badawczego), zaplanowanie in- 
nowacji, wprowadzenie innowacji, ewaluację oraz instytucjonalizację (czyli włączenie innowacji w praktykę szkolną w danym miejscu). Według Paradies i Linser (2008: 17) rozwój organizacyjny szkoły służy zaplanowanemu kształtowaniu i odnawianiu architektury społecznej szkoły przy współudziale pedagogicznym wszystkich zainteresowanych.

Wprowadzając zatem atrakcyjne formy międzykulturowego nauczania i uczenia się języków obcych, trzeba mieć na uwadze interpretowanie ich jako innowacyjności i długoterminowe ich włączanie w proces kształcenia, bowiem „uczenie się i nauczanie kompetencji międzykulturowych mają kluczowe znaczenie dla kultury demokratycznej i spójności społecznej” (Biała Księga Dialogu Międzykulturowego; za: Byram i in., 2011: 6). Kompetencja międzykulturowa obejmuje następujące podstawowe kompetencje:

- $\quad$ kompetencje poznawcze (np. wiedzę o innych grupach kulturowych);

- kompetencje emocjonalne (np. postawę otwartości, ciekawości, szacunku dla innych, empatii);

- kompetencje behawioralne (np. umiejętność interpretowania, porównywanie, odkrywczość, krytyczną świadomość kulturową) (por. Byram i in., 2011: 12 i n.).

Rozwój w/w kompetencji związany jest bezpośrednio z realizacją podstawowych celów nauczania i uczenia się języków obcych (por. Doyé, 1995: 16 i n.), takich jak, cele kognitywne (odpowiadające za rozwój kompetencji poznawczych), cele afektywne (kształcące kompetencje emocjonalne) i cele społeczno-pragmatyczne (uwzględniające kompetencje behawioralne).

\section{Rozwiązania glottodydaktyczne sprzyjające innowacyjności}

W dalszym toku rozważań ukazane zostaną przykładowe formy uczenia się i nauczania, które sprzyjają innowacyjności w obszarze glottodydaktyki. Wydaje się, iż każda z dalej przedstawionych form może w sposób optymalny wspierać realizację nadrzędnego celu nauczania i uczenia się języków obcych, jakim jest omówiona powyżej kompetencja komunikacyjna z jej uściśleniem jako kompetencji międzykulturowej. Formy wybrane do celów tej analizy ukazane zostaną z dwóch perspektyw: z jednej strony (horyzontalnie) rozróżnione zostaną za Paradies i Linser (2008) formy zindywidualizowanego, wspólnego i frontalnego uczenia się oraz nauczania języków obcych, z drugiej strony (wertykalnie) - w zestawieniu własnym - glottodydaktyczne formy o charakterze zamkniętym, półotwartym i otwartym. Na tej podstawie zaproponowana zostanie własna typologia innowacyjnych form międzykulturowego uczenia się i nauczania języków obcych. 


\subsection{Formy zindywidualizowanego, wspólnego i frontalnego uczenia się i nauczania}

W literaturze przedmiotu wyróżnia się trzy podstawowe typy lekcji (horyzontalnie):

- lekcje o charakterze frontalnym, zbudowane w dużej mierze z frontalnych dydaktycznych sytuacji uczenia się i nauczania;

- lekcje o charakterze kooperacyjnym, składające się w dużej mierze ze wspólnych dydaktycznych sytuacji uczenia się i nauczania;

- lekcje o charakterze zindywidualizowanym, które zbudowane są w dużej mierze z dydaktycznych sytuacji uczenia się i nauczania, bazujących na indywidualnej ich organizacji (por. Paradies i Linser, 2008: 29).

Dalej przedstawiono zestawienie przykładowych form zindywidualizowanego, kooperacyjnego i frontalnego uczenia się i nauczania (horyzontalnie).

\begin{tabular}{|c|c|}
\hline $\begin{array}{l}\text { Formy frontalnego } \\
\text { uczenia się i nauczania j.o. }\end{array}$ & $\begin{array}{ll}\text { - } & \text { tradycyjna lekcja z całą klasą; } \\
\text { - } & \text { prezentacja (np. multimedialna lub z wykorzystaniem metaplanu); } \\
\text { - } & \text { praca z tablicą interaktywną; } \\
\text { - } & \text { uczenie się przez nauczanie } \\
\end{array}$ \\
\hline $\begin{array}{l}\text { Formy wspólnego } \\
\text { uczenia się i nauczania j.o. }\end{array}$ & $\begin{array}{ll}\text { - } & \text { praca projektowa (w tym projekty internetowe, wymiana młodzieży); } \\
\text { - } & \text { drama; } \\
\text { - warsztaty dydaktyczne; } \\
\text { - } & \text { wspólne świętowanie; } \\
\text { - } & \text { wycieczki klasowe, uczniowska wymiana; } \\
\text { - } & \text { opracowanie biografii spotkań międzykulturowych } \\
\end{array}$ \\
\hline $\begin{array}{l}\text { Formy } \\
\text { zindywidualizowanego } \\
\text { uczenia się i nauczania j.o. }\end{array}$ & $\begin{array}{l}\text { - } \text { praca swobodna; } \\
\text { - } \text { praca w formie stanowisk dydaktycznych; } \\
\text { - } \text { samodzielna praca w domu; } \\
\text { - } \text { samodzielna praca z wykorzystaniem komputera; } \\
\text { - } \text { samodzielne wycieczki; } \\
\text { - } \text { praca z portfolio językowym; } \\
\text { - } \text { praca z dziennikiem uczenia się; } \\
\text { - } \text { prowadzenie korespondencji między-klasowej }\end{array}$ \\
\hline
\end{tabular}

Tabela 1: Formy zindywidualizowanego, wspólnego i frontalnego uczenia się i nauczania języków obcych (opracowanie własne; na podstawie Paradies i Linser, 2008).

Wymienione typy lekcji tworzą swego rodzaju scenariusz dla zaistnienia różnorodnych sytuacji dydaktycznych.

\subsection{Formy zamkniętego, otwarto-zamkniętego i otwartego uczenia się i nauczania}

Drugą perspektywę (wertykalną) można nakreślić analizując odpowiedź na pytanie, w jakim stopniu dana forma lekcji przejawia charakter otwarty. Mówiąc 
o otwartości bierze się pod uwagę otwartość metodyczną, organizacyjno-treściową i społeczną (Peschel, 2005). Wszystkie przedstawione poniżej typy lekcji uwzględniają zarówno elementy nauczania frontalnego, jak wspólnego (zespołowego i w parach) oraz indywidualnego.

\begin{tabular}{|c|c|c|}
\hline $\begin{array}{c}\text { Formy zamkniętego uczenia } \\
\text { się i nauczania j.o. }\end{array}$ & $\begin{array}{l}\text { Formy otwarto-zamkniętego } \\
\text { uczenia się i nauczania j.o. }\end{array}$ & $\begin{array}{c}\text { Formy otwartego uczenia się } \\
\text { i nauczania j.o. }\end{array}$ \\
\hline $\begin{array}{l}\text { - praca z dziennikiem uczenia się; } \\
\text { - drama; } \\
\text { - tradycyjna lekcja z całą klasą; } \\
\text { - prezentacja multimedialna }\end{array}$ & $\begin{array}{l}\text { - } \text { praca z tablicą interaktywną; } \\
\text { - } \text { praca z portfolio językowym; } \\
\text { - międzyklasowej; } \\
\text { - warsztaty dydaktyczne; } \\
\text { - opracowanie biografii spotkań } \\
\text { międzykulturowych; } \\
\text { - uczenie się przez nauczanie; } \\
\text { - samodzielna praca w domu; } \\
\text { - samodzielna praca z wykorzy- } \\
\text { staniem komputera; } \\
\text { - wspólne świętowanie; } \\
\text { - wycieczki klasowe, uczniow- } \\
\text { ska wymiana }\end{array}$ & $\begin{array}{l}\text { - } \text { praca swobodna; } \\
\text { - praca według planu dnia/tygo- } \\
\text { dnia; } \\
\text { - praca w formie stanowisk dy- } \\
\text { daktycznych; } \\
\text { - praca projektowa }\end{array}$ \\
\hline
\end{tabular}

Tabela. 2: Formy zamkniętego, otwarto-zamkniętego i otwartego uczenia się i nauczania języków obcych (opracowanie własne).

Można zatem zasugerować rozróżnienie następujących podstawowych typów lekcji:

- lekcje o charakterze zamkniętym, a więc raczej tradycyjne lekcje, na których nauczyciel i uczniowie realizują przypisane im od wieków funkcje: nauczyciel jest kompetentną osobą przekazującą wiedzę i kształtującą umiejętności uczniów jako dużej grupy;

- lekcje o charakterze półotwartym, a więc z jednej strony zamkniętym, z drugiej otwartym, na których dokłada się starań, by ukierunkować działania dydaktyczne na potrzeby uczniów;

- lekcje o charakterze otwartym, które realizują w sposób optymalny zasady otwartości metodycznej, organizacyjno-treściowej i społecznej; są to lekcje, na których praca i procesy uczenia się oraz nauczania przebiegają w sposób otwarty.

\subsection{Próba usystematyzowania innowacyjnych rozwiązań glottodydaktycznych}

Nie jest możliwe uczenie się i nauczanie języków obcych o charakterze otwartym w formie frontalnej. Te dwa aspekty wykluczają się. Otwarte podejście w glottodydaktyce oznacza zgodę na odejście od nauczania frontalnego (nawet 
w jego najnowocześniejszych formach) w kierunku form wspólnego i zindywidualizowanego otwartego uczenia się.

Wszystkie dotychczas omówione formy uczenia się i nauczania zostały zebrane w poniższej tabeli (horyzontalnie i wertykalnie).

\begin{tabular}{|c|c|c|c|}
\hline & $\begin{array}{c}\text { Formy zamkniętego } \\
\text { uczenia się } \\
\text { i nauczania j.o. } \\
\end{array}$ & $\begin{array}{c}\text { Formy otwarto-zamknię- } \\
\text { tego uczenia się } \\
\text { i nauczania j.o. }\end{array}$ & $\begin{array}{c}\text { Formy otwartego } \\
\text { uczenia się } \\
\text { i nauczania j.o. }\end{array}$ \\
\hline $\begin{array}{l}\text { Formy frontalnego } \\
\text { uczenia się i nauczania } \\
\text { j.o. }\end{array}$ & $\begin{array}{l}\text { - prezentacja multi- } \\
\text { medialna } \\
\text { - tradycyjna lekcja z } \\
\text { całą klasą }\end{array}$ & $\begin{array}{l}\text { - praca z tablicą interak- } \\
\text { tywną } \\
\text { - uczenie się przez naucza- } \\
\text { nie }\end{array}$ & - \\
\hline $\begin{array}{l}\text { Formy kooperacyjnego } \\
\text { uczenia się i nauczania } \\
\text { j.o. }\end{array}$ & - drama & $\begin{array}{l}\text { - warsztaty dydaktyczne } \\
\text { - opracowanie biografii } \\
\text { spotkań międzykulturo- } \\
\text { wych } \\
\text { - wspólne świętowanie } \\
\text { - wycieczki klasowe, ucz- } \\
\text { niowska wymiana }\end{array}$ & - praca projektowa \\
\hline $\begin{array}{l}\text { Formy } \\
\text { zindywidualizowanego } \\
\text { uczenia się i nauczania } \\
\text { j.o. }\end{array}$ & $\begin{array}{l}\text { - praca z dziennikiem } \\
\text { uczenia się }\end{array}$ & $\begin{array}{l}\text { - samodzielna praca w } \\
\text { domu } \\
\text { - samodzielna praca z wy- } \\
\text { korzystaniem komputera } \\
\text { - samodzielne wycieczki } \\
\text { - praca z portfolio języko- } \\
\text { wym } \\
\text { - prowadzenie korespon- } \\
\text { dencji międzyklasowej }\end{array}$ & $\begin{array}{l}\text { - praca w formie stano- } \\
\text { wisk dydaktycznych } \\
\text { - praca według planu } \\
\text { dnia/tygodnia } \\
\text { - praca swobodna }\end{array}$ \\
\hline
\end{tabular}

Tabela. 3: Innowacyjne rozwiązania glottodydaktyczne (opracowanie własne).

Poszczególne rozwiązania glottodydaktyczne sprzyjające innowacyjności, wraz ze wskazaniem, w jaki sposób mogą być stosowane w praktyce glottodydaktycznej celem rozwoju kompetencji międzykulturowej, zostały poniżej zamieszczone w kolejności alfabetycznej. Każda z nich została odpowiednio zaklasyfikowana (wertykalnie i horyzontalnie), zgodnie z powyższą tabelą:

\footnotetext{
- Biografia spotkań międzykulturowych (półotwarta forma kooperacyjnego uczenia się i nauczania języków obcych)

Jest to taka forma pracy na lekcji, w ramach której nauczyciel i uczniowie wspólnie dokumentują przebieg międzykulturowych spotkań, mających miejsce na przykład podczas wymiany młodzieży. Praca ta koncentruje się wokół „refleksji nad rozwojem osobistym opartym na doświadczeniu oraz nad wartościami, poglądami i zachowaniami wszystkich stron uczestniczących w tego typu spotkaniach" (Byram i in., 2011: 7). Uczniowie wspólnie z nauczycielem opisują w języku obcym swoje doświadczenia i przeżycia w formie dziennika.
} 
- Drama (zamknięta forma kooperacyjnego uczenia się i nauczania języków obcych)

Ta forma pracy na lekcji i poza nią sprzyja rozwijaniu kompetencji związanych z kooperacją. Polega na wspólnym przygotowaniu przez nauczyciela i uczniów form teatralnych o różnorodnej specyfice, takich jak np. przedstawienie teatralne, scenki tematyczne, pantomima (później omawiana w języku obcym), przedstawienia kukiełkowe, teatr cieni. Forma ma charakter zamknięty, jeśli opiera się na wcześniej zaakceptowanym scenariuszu. Dzięki odpowiedniej tematyce uczniowie poznają kulturę kraju docelowego i porównują ją z własną, np. przygotowując sztuki autorów tego kraju.

- Korespondencja międzyklasowa (półotwarta forma zindywidualizowanego uczenia się i nauczania języków obcych)

Poszczególni uczniowie biorą udział w formie projektu: jako klasycznej wymianie listów lub internetowo np. za pośrednictwem e-maili, facebooka. Każdy indywidualnie angażuje się w relację z konkretną osobą z innego (niekoniecznie docelowego) kraju. Ważny jest język komunikacji - dany język obcy dla uczących się.

- Praca projektowa (otwarta forma kooperacyjnego uczenia się i nauczania języków obcych) Ta forma pracy polega na wspólnym (przez nauczyciela i uczniów) inicjowaniu, planowaniu i opracowaniu projektów (w tym projektów internetowych, wymiany młodzieży). Osoby biorące udział w projekcie określają w pierwszej linii jego tematykę (związaną z ogólnym tematem danej lekcji) oraz formę (wizualną, np. plakat, wykres, schemat, collage; audytywną, np. nagranie wywiadu, opracowanie piosenki; audiowizualną, np. nagranie filmiku, reklamy; kreatywną, np. przygotowanie potrawy typowej dla danego obszaru językowego). Praca projektowa może zakończyć się zrealizowaniem zaplanowanego projektu, jego zmianą lub brakiem realizacji (np. z powodu konfliktów w zespole). Te wszystkie trzy możliwe zakończenia pracy projektowej mają sens z punktu widzenia glottodydaktyki, gdyż zawsze rozwijają kompetencję międzykulturową (w tym komunikacyjną) w języku obcym.

- Praca swobodna (otwarta forma zindywidualizowanego uczenia się i nauczania języków obcych)

Ta forma pracy na lekcji jest formą o najbardziej otwartej strukturze. Uczniowie mają tu pełną możliwość samodzielnej pracy i decydowania o zakresie planowania czasu pracy, zadań, formy społecznej, doboru materiałów. Jest to praca bez kierownictwa nauczyciela. Uczeń sam decyduje, jak będzie pracował na lekcji, pozostając w ramach omawianego tematu. Korzystając z atrakcyjnych materiałów dydaktycznych (np. tekstów, nagrań, filmów), uzupełniających (np. z Internetu, słowników, leksykonów, map, folderów) oraz pomocniczych (np. dużych i małych arkuszy papieru, markerów, telefonów komórkowych, aparatów fotograficznych) uczniowie poznają kraj docelowy z perspektywy własnych, osobistych zainteresowań i opracowują interesujące ich tematy samodzielnie i na własny sposób.

- Praca w formie stanowisk dydaktycznych (otwarta forma zindywidualizowanego uczenia się i nauczania języków obcych)

Ta forma pracy polega na samodzielnym wykonywaniu zadań przygotowanych przedtem przez nauczyciela na odpowiednich stanowiskach dydaktycznych. Uczniowie zakreślają każde samodzielnie wykonane zadanie na tzw. karcie obiegowej. Poszczególne stanowiska powinny rozwijać rożne sprawności i kompetencje językowe w sposób zintegrowany oraz umożliwiać pozna- 
wanie kultur obcych krajów, np. poszukiwanie w folderze turystycznym informacji o kilku zabytkach; wysłuchanie pilota wycieczek, oprowadzającego po stolicy kraju docelowego; opowiadanie o spotkaniu z przedstawicielem innej kultury; napisanie wiersza na temat spotkania. - Praca według planu dnia/tygodnia (otwarta forma zindywidualizowanego uczenia się i nauczania języków obcych)

Uczniowie wykonują samodzielnie zadania zamieszczone w planie dnia lub tygodnia. Sami decydują o kolejności i tempie wykonania, ewentualnym doborze partnerów do pracy, korzystaniu z materiałów. Realizując zadania obowiązkowe, fakultatywne i dodatkowe uczniowie rozwijają własną kompetencję międzykulturową. Mogą np. obowiązkowo rozwiązać szereg ćwiczeń gramatycznych dot. form czasowników, fakultatywnie zapisać te formy na dwujęzycznych fiszkach i dodatkowo przygotować memory lub domino z ich wykorzystaniem.

Praca z dziennikiem uczenia się (zamknięta forma zindywidualizowanego uczenia się i nauczania języków obcych)

Uczniowie wypełniają indywidualnie własne dzienniki uczenia się (podczas lekcji lub po jej zakończeniu). Jest to rodzaj pamiętnika, w którym odnotowywane są zarówno przebieg procesu uczenia się, jak i osobista refleksja nad nim. Dziennik, przygotowany uprzednio przez nauczyciela, stanowi zbiór osobistych notatek danego ucznia i może stanowić alternatywę tradycyjnego zeszytu. Są to odpowiednie pytania lub punkty, według których uczeń zdobywa się na indywidualną refleksję nad przebiegiem własnego procesu uczenia się, koncentrując się przy tym przede wszystkim na doświadczeniach związanych z międzykulturowymi sytuacjami uczenia się.

- Praca z portfolio językowym (półotwarta forma zindywidualizowanego uczenia się i nauczania języków obcych)

Idea portfolio językowego zaczerpnięta została od Europejskiego Portfolio Językowego. Istotą dydaktycznego portfolio (podobnie jak w EPJ) jest gromadzenie i opracowywanie przez danego ucznia własnych materiałów językowych. Uczeń dokumentuje swój proces uczenia się na danej lekcji, na sekwencji kilku lekcji lub na przestrzeni kilku miesięcy. Wiele podręczników do nauki języków obcych wykorzystuje aktualnie pomysł portfolio. Nauczyciel może zaproponować też własne dydaktyczne portfolio językowe (np. tylko dotyczące tematu „Święta i zwyczaje w Polsce i ...", „Muzyka w Polsce i ... , , , "Miasta Polski i ..." ).

- Praca z tablicą interaktywną (półotwarta forma frontalnego uczenia się i nauczania języków obcych)

Nowoczesna forma pracy na lekcji znana jest z jej funkcji motywującej. Różnorodność możliwości pracy z tablicą interaktywną nie ma w zasadzie granic. Istotne jest połączenie jej funkcji jako medium audio, video, audiowizualnego oraz elektronicznego. Uczniowie zyskują wyjątkowo ciekawą szansę poznawania kultury kraju docelowego w aktywny sposób, np. poprzez rozwiązywanie quizów internetowych, opracowywanie projektów, oglądanie filmów, słuchanie wypowiedzi rodzimych użytkowników języka, oglądanie wideoklipów. Istotna jest możliwość redagowania, dowolnego zmieniania prezentowanego materiału oraz jego zapisu, a następnie elektronicznego wysyłania do poszczególnych uczniów i udostępniania innym osobom i instytucjom. Nie należy jednak zapominać, iż jest to forma frontalnego nauczania. 
- Prezentacja (zamknięta forma frontalnego uczenia się i nauczania języków obcych)

Uczniowie lub nauczyciel przygotowują prezentację określonego materiału dotyczącego obcej kultury w formie prezentacji multimedialnej (np. statycznej Power Point lub dynamicznej Prezi), w formie plakatu, collage'u, z wykorzystaniem kart i zbudowaniem metaplanu itp.

- Samodzielna praca w domu (półotwarta forma zindywidualizowanego uczenia się i nauczania języków obcych)

Aby można było mówić o tej formie pracy na lekcji języka obcego, należałoby uprzednio opracować odpowiednie zadania. Obok typowego samodzielnego rozwiązywania zadań w ramach pracy własnej w domu uwzględnia się aktualnie listy zadań do wykonania, obejmujące (podobnie jak podczas pracy z planem dnia/ tygodnia) zadania obowiązkowe, fakultatywne i do wyboru. Tylko w ten sposób może być zapewniony pół-otwarty charakter takiej formy z uwzględnieniem prezentacji jej różnorodnych wyników na forum podczas lekcji. Uczniowie mogą jako zadanie obowiązkowe np. samodzielnie gromadzić informacje o krajach, w których dany język obcy jest językiem komunikacji, jako zadanie fakultatywne np. sporządzić wizualne zestawienie tych informacji, jako zadanie dodatkowe np. przedstawić te informacje $\mathrm{w}$ formie własnego reportażu.

- Samodzielna praca z wykorzystaniem komputera (półotwarta forma zindywidualizowanego uczenia się i nauczania języków obcych)

W tej formie uczeń samodzielnie decyduje o zakresie zadań wykonywanych za pośrednictwem komputera, może to być na przykład poszukiwanie informacji w Internecie, udział w obcojęzycznych forach oraz w komunikacji poprzez facebook, uczenie się języka z wykorzystaniem internetowych gier edukacyjnych, opracowanie multimedialnych obcojęzycznych prezentacji o kraju docelowym i Polsce, itp.

- Tradycyjna lekcja z całą klasą (zamknięta forma frontalnego uczenia się i nauczania języków obcych)

W nauczaniu tradycyjnym kładzie się przeważnie nacisk na rozwój jednej sprawności językowej. Uwzględnia się zatem ćwiczenia mocno-, lekkosterowane i swobodne (w przypadku rozwijania sprawności mówienia i pisania) lub ćwiczenia poprzedzające, towarzyszące, sprawdzające i pogłębiające (w przypadku rozwijania sprawności czytania i rozumienia ze słuchu). Wszystkie mogą rozwijać kompetencję międzykulturową.

- Uczenie się przez nauczanie (półotwarta forma frontalnego uczenia się i nauczania języków obcych)

Ta forma pracy na lekcji zakłada wcześniejsze jej przygotowanie przez wybrany tandem uczniów (pod kierunkiem nauczyciela). Uczniowie ci starają się potem na danej lekcji przekazać pozostałym wiedzę i umiejętności, które uprzednio samodzielnie nabyli. W przypadku kształcenia kompetencji międzykulturowej uczniowie mogą np. samodzielnie wybierać materiały i tematy, a następnie pod kierownictwem nauczyciela przygotowywać lekcje np. na temat zwyczajów żywieniowych i tradycyjnych potraw w kraju docelowym i w Polsce.

- Warsztaty dydaktyczne (półotwarta forma kooperacyjnego uczenia się i nauczania języków obcych)

Nie należy mylić tej formy pracy z uczeniem się na stanowiskach dydaktycznych. Tutaj zespołom uczniów, dobranym samodzielnie lub wyznaczonym przez nauczyciela, przyznane zostają kreatywne zadania do wykonania. Zazwyczaj każdy zespół zajmuje się innym zadaniem lub in- 
nym zagadnieniem i dopiero prezentacja wszystkich wyników uwydatnia cały zakres omawianego problemu. Można np. zaproponować uczniom pracę w poszczególnych zespołach nad stylami zabudowy w kraju docelowym i Polsce, typowym wyposażeniem domów i mieszkań, projektami mieszkań i domów, a następnie zachęcić uczniów do zebrania tych informacji w jednym folderze pt. „Domy i mieszkania w Polsce i ...”.

- Wspólne świętowanie (półotwarta forma kooperacyjnego uczenia się i nauczania języków obcych)

Nauczyciel oraz uczniowie przygotowują jako formę projektu wspólne świętowanie określonych wydarzeń: świąt, uroczystości charakterystycznych dla kultury kraju docelowego. Celem nie jest przejęcie tych zwyczajów jako własnych, lecz ich poznanie (np. od strony kulinarnej, muzycznej, artystycznej, społeczno-rodzinnej).

- Wycieczki klasowe, uczniowska wymiana (półotwarta forma kooperacyjnego uczenia się i nauczania języków obcych)

Jest to forma długoterminowego projektu, którego celem jest „zanurzenie” w kulturze kraju docelowego i aktywne poznanie go w wielu wymiarach. Charakterystyczna jest nowa rola nauczyciela w takiej glottodydaktycznej sytuacji. Podczas wymiany aktywność poszczególnych uczniów jest jeszcze wyższa, a kompetencja międzykulturowa rozwijana w sposób zarówno celowy, jak i nieświadomy.

Tabela 4: Innowacyjne rozwiązania glottodydaktyczne w kształceniu kompetencji międzykulturowej (opracowanie własne).

\section{Propozycja typologii form pracy międzykulturowego uczenia się $\mathbf{i}$ nauczania języków obcych}

We wszystkich wyżej przedstawionych formach może mieć miejsce realizacja nadrzędnego celu nauczania języków obcych, jakim jest rozwijanie kompetencji międzykulturowej. Nie ma większego sensu typologia form, rozróżniająca formy „monokulturowe” (a więc skoncentrowane na przekazywaniu treści o jednej obcej kulturze), formy „dwukulturowe” (gdzie uczniowie zdobywają się na porównanie dwóch kultur: własnej i obcej, a więc kraju docelowego) i formy międzykulturowe (gdzie w ekstremalny sposób dokonuje się komparacja wielu kultur). W każdej z przedstawionych dotychczas form pracy mogą uczniowie koncentrować się na jednej kulturze, dwóch lub wielu.

Do ciekawych wniosków można dojść natomiast dokonując diagonalnej analizy wyżej przedstawionej tabeli, zawierającej usystematyzowany przegląd form: horyzontalnie, $\mathrm{tj}$. od frontalnego do zindywidualizowanego uczenia się $\mathrm{i}$ nauczania, oraz wertykalnie, tj. od zamkniętego do otwartego uczenia się języków obcych. Otóż okazuje się, że da się rozróżnić podające, aktywizujące i otwarte formy międzykulturowego uczenia się i nauczania języków obcych, co zostało przedstawione poniżej. 
Podające formy międzykulturowego uczenia się i nauczania języków obcych są zamkniętymi formami frontalnymi, takimi jak tradycyjna lekcja z całą klasą, prezentacja multimedialna, praca z tablicą interaktywną. Na takich lekcjach języków obcych nauczyciel podaje materiał międzykulturowy tylko do odbioru i analizy. Są to zatem takie lekcje, na których uczniowie pod kierownictwem nauczyciela (z wykorzystaniem odpowiednich, atrakcyjnych, w tym autentycznych materiałów) dokonują porównania własnej kultury z kulturą kraju docelowego. Nacisk zostaje położony na realizację celów kognitywnych i rozwój wspomnianych wcześniej kompetencji poznawczych.

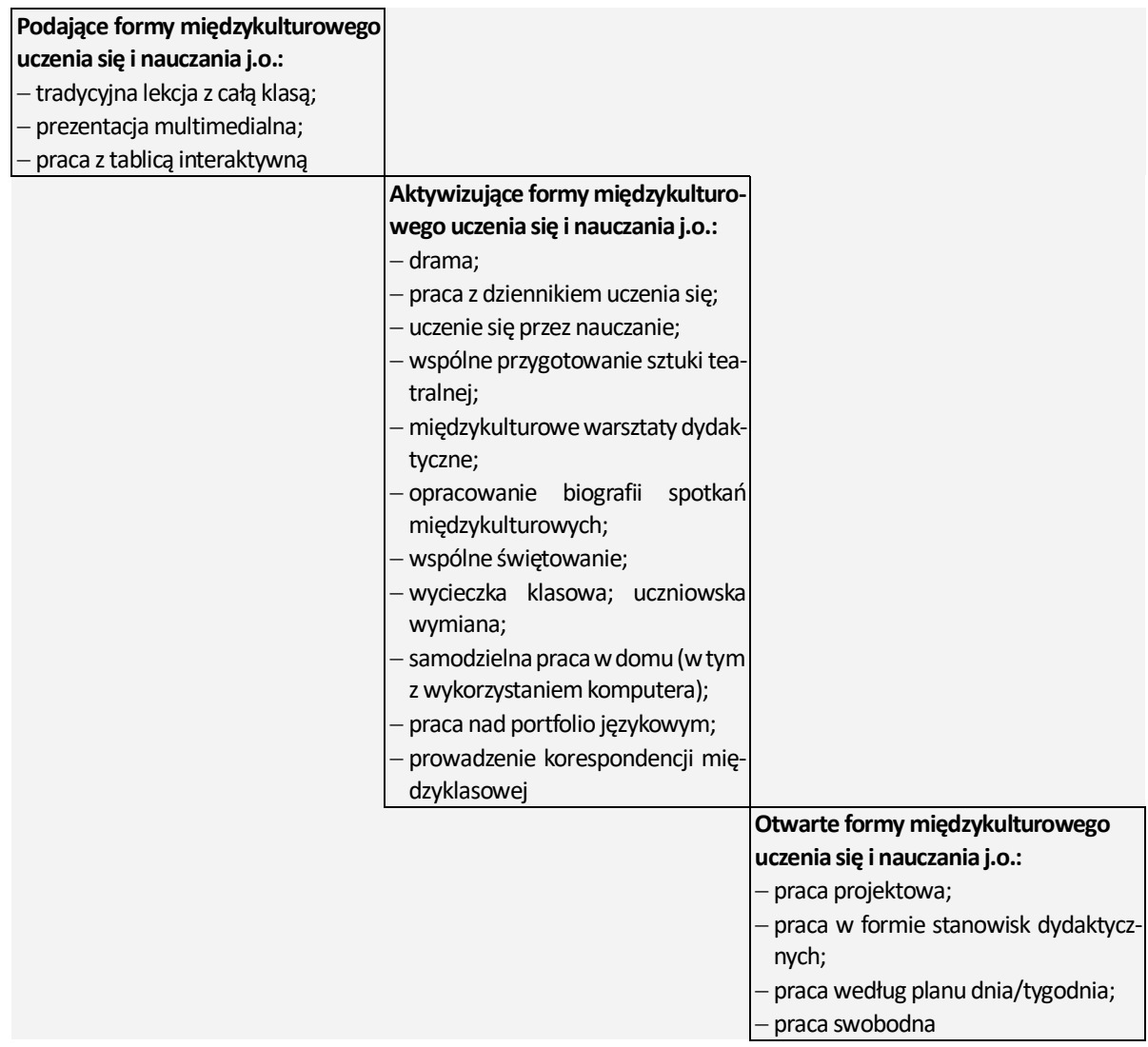

Tabela 5: Typologia form międzykulturowego uczenia się i nauczania języków obcych (opracowanie własne).

Aktywizujące formy międzykulturowego uczenia się i nauczania języków obcych obejmują zamknięte i otwarto-zamknięte formy frontalnego, kooperacyjnego i zindywidualizowanego uczenia się i nauczania języków obcych. Są to takie formy pracy na lekcji i poza nią, podczas których uczniowie aktywnie, ale 
pod kierownictwem nauczyciela-moderatora dokonują wspólnie lub indywidualnie porównania kultury własnej i kultury kraju docelowego. Mogą to być formy frontalne, jak uczenie się przez nauczanie, a także formy kooperacyjne, jak wspólne przygotowanie sztuki teatralnej, międzykulturowe warsztaty dydaktyczne, opracowanie biografii spotkań międzykulturowych, wspólne świętowanie, wycieczka klasowa oraz formy zindywidualizowane, jak prowadzenie dziennika uczenia się, samodzielna praca w domu (w tym z wykorzystaniem komputera), uczenie się poza szkołą, praca z portfolio językowym, prowadzenie korespondencji międzyklasowej. Charakterystyczna przy tym jest aktywna postawa ucznia, a szczególnego znaczenia nabiera realizacja celów afektywnych i rozwój jego kompetencji emocjonalnych.

Otwarte formy międzykulturowego uczenia się i nauczania języków obcych obejmują otwarte formy kooperacyjnego i zindywidualizowanego uczenia się i nauczania języków obcych. Są to takie formy pracy na lekcji lub poza nią, podczas których uczniowie (zespołowo lub indywidualnie) bez kierownictwa nauczyciela dokonują samodzielnego porównania kultury własnej i kraju docelowego. Otwartymi formami międzykulturowego uczenia się i nauczania są praca projektowa, praca $w$ formie stanowisk dydaktycznych, praca według planu dnia/tygodnia oraz praca swobodna. Podczas pracy w tych formach szczególnego znaczenia nabierają samodzielne poszukiwania i doświadczenia każdego ucznia. Prymarna jest realizacja celów społeczno-pragmatycznych i rozwój kompetencji behawioralnych zorientowany na działanie, rozumiane jako „gotowość do podejmowania po uprzednim namyśle samodzielnej lub grupowej aktywności na rzecz wspólnego dobra" (Byram i in., 2011: 30).

\section{Podsumowanie i perspektywy badawcze}

Przedstawione w niniejszym opracowaniu formy międzykulturowego uczenia się i nauczania języków obcych są znane w glottodydaktyce. Ich innowacyjne zastosowanie polega na systematycznym wykorzystaniu na lekcjach językowych. Po zbadaniu sytuacji wyjściowej dotyczącej danej grupy, a także środowiska i czasu, w jakich te formy mają być stosowane, oraz uzyskaniu akceptacji np. ze strony dyrekcji szkoły, nauczyciel języków obcych może zdecydować się na ich zastosowanie. Wprowadzenie danej formy międzykulturowego uczenia się i nauczania języków obcych zostaje następnie precyzyjnie zaplanowane, zrealizowane i ocenione. Z pewnością takie innowacyjne wykorzystanie wymienionych form pracy przyczyni się do rozwoju kompetencji międzykulturowej uczniów oraz do kształtowania i odnawiania architektury społecznej szkoły, jak to zostało zaakcentowane w pierwszej sekcji niniejszego artykułu. Tylko długoterminowe włączenie zestawionych tu we własną typologię form 
międzykulturowego uczenia się i nauczania języków obcych może w rzeczywistości rozwinąć kompetencję międzykulturową uczniów, rozumianą jako uszczegółowienie kompetencji komunikacyjnej.

Prowadzone już w latach 2002-2005 badania własne nad otwartymi formami pracy w gimnazjum ukazały, iż tylko systematyczne i długoterminowe realizowanie takich innowacji może przynieść jako rezultat rozwój kompetencji komunikacyjnej. Podobne wnioski nasuwały się po zrealizowanych w roku 2014 własnych badaniach pilotażowych nad otwartymi formami pracy w akademickim kształceniu nauczycieli języków obcych na Uniwersytecie Warszawskim.

Dobrze byłoby wprowadzić do szkół na zasadzie innowacji również pozostałe formy międzykulturowego uczenia się i nauczania języków obcych, poddając empirycznej weryfikacji ich zastosowanie z perspektywy rozwoju kompetencji międzykulturowej. Interesujące mogłoby być porównanie ich efektów w tym zakresie na różnych poziomach edukacyjnych (podstawowym, gimnazjalnym i ponadgimnazjalnym), a także w kształceniu akademickim. Można zbadać, w jaki sposób rozwijana jest kompetencja międzykulturowa poprzez zastosowanie tylko podających, wyłącznie aktywizujących lub jedynie otwartych form międzykulturowego uczenia się i nauczania języków obcych. Rezultatem takich badań empirycznych mogłoby być kompendium takich form, dedykowane nauczycielom języków obcych, zawierające przykłady tzw. dobrych praktyk w tym zakresie. Bowiem według Białej Księgi Dialogu Międzykulturowego „żyjemy razem równi w godności”, zatem „należy stworzyć dodatkowe materiały metodyczne, które pomogą uczniom kształtować umiejętności bazujące na samodzielności, w tym umiejętności dotyczące krytycznej refleksji nad własnymi reakcjami i postawami wobec swoich doświadczeń z innymi kulturami" (http://www.coe.int/dialogue; za: Byram i in., 2011: 3).

Każda z przedstawionych w powyższej typologii form pracy pomaga uczniom uświadomić sobie kompetencje, jakie posiadają oraz nabyć nowe kompetencje o charakterze międzykulturowym. Niniejszy artykuł jest próbą usystematyzowania takich form uczenia się nauczania języków obcych, w których w wyjątkowy sposób możliwe jest eksponowanie aspektu międzykulturowego. Być może będzie stanowić inspirację dla badaczy, by podjąć pogłębione badania empiryczne $w$ dziedzinie glottodydaktyki w tym zakresie.

Jako podsumowanie pozwolę sobie przywołać wypowiedź Byrama i in. (2011: 13): „Nieodłącznym aspektem analiz spotkań międzykulturowych jest refleksja nad powiązaniem świeżo nabytej wiedzy z rozumieniem samego siebie i z wyznawanymi wartościami". Takiego inspirującego poznawania innych kultur, bez zagrożeń, a z szacunkiem dla ludzkiej godności i w przyjaznym środowisku życzę badaczom, nauczycielom, uczniom i sobie. 


\section{BIBLIOGRAFIA}

Byram, M. i in. 2011. Autobiografia spotkań międzykulturowych. Warszawa: Ośrodek Rozwoju Edukacji.

de Cillia, R., Haller, M., i B. Kettemann. 2005. Innovation im Fremdsprachenunterricht. Frankfurt am Main: Peter Lang.

Doyé, P. 1995: „Lehr- und Lernziele”. (w) Handbuch Fremdsprachenunterricht. (red. K.R. Bausch, H. Christ i H.J. Krumm). Tübingen/ Basel: Francke Verlag, str. 161-166.

Gajek, E. 2004. Edukacja językowa w Unii Europejskiej. Informator i przewodnik internetowy dla nauczycieli. Warszawa: Fraszka Edukacyjna.

Heyd, G. 1997. Aufbauwissen für den Fremdsprachenunterricht (DaF). Narr Verlag: Tübingen.

Karpeta-Peć, B. 2008. Otwarty, aktywny, samodzielny ... Alternatywne formy pracy. Przewodnik dla nauczycieli języków obcych. Warszawa: Fraszka Edukacyjna.

Krumm, H. J. 1995: „Interkulturelles Lernen und interkulturelle Kommunikation”. (w) Handbuch Fremdsprachenunterricht. (red. K.R. Bausch, H. Christ i H.J. Krumm). Tübingen/ Basel: Francke Verlag, str. 156-161.

Paradies, L. i H.-J. Linser. 2008. Differenzieren im Unterricht. Berlin: Cornelsen Scriptor. Torenc, M. 2007. Nauczanie miedzykulturowe - implikacje glottodydaktyczne. Wrocław: Oficyna Wydawnicza ATUT.

\section{Netografia}

Biała Księga Dialogu Międzykulturowego. Żyjemy razem równi w godności. Online: http://www.coe.int/dialogue; http://www.coe.int/t/dg4/intercultural (DW 15.01.16).

Peschel, F: Stufenmodell des Offenen Unterrichts. 2005. Online: http://www.uni-konstanz. de/ag-moral/lernen/11_offenes-lernen/ou_stufenmodell_peschel_dateien/in fo.htm (DW 04.09.15). 